\title{
EVALUASI PEMBERIAN CRUDE PROTEIN Zoothamnium penaei TERHADAP LAJU PERTUMBUHAN, RESPON IMUN DAN KELULUSHIDUPAN UDANG VANAME (Litopenaeus vannamei) DI TAMBAK
}

\author{
Ricat Pahlefi Hidayat ${ }^{1}$, Suwarno $^{2}$, Gunanti Mahasri ${ }^{3}$ \\ ${ }^{1}$ Mahasiswa Program Studi Bioteknologi Perikanan dan Kelautan Sekolah Pascasarjana \\ Universitas Airlangga \\ ${ }^{2}$ Fakultas Kedokteran Hewan Universitas Airlangga \\ ${ }^{3}$ Sekolah Pascasarjana Universitas Airlangga \\ Kampus B Unair, Jl. Airlangga, Surabaya \\ Telepon 031-5041566 \\ Email : ricat_perak@yahoo.co.id
}

\begin{abstract}
Abstrak
Kendala utama dalam budidaya udang vaname adalah munculnya serangan penyakit yang dapat menyebabkan kematian hingga 100\% setelah 2 sampai 3 hari setelah infeksi. Tujuan penelitian ini untuk menganalisi respon imun, laju pertumbuhan spesifik dan kelulushidupan udang vaname (Litopenaeus vannamei). Metode penelitian adalah eksperimental untuk mengetahui pengaruh penggunaan pakan dan ditambahkan crude protein Zoothamnium penaei pada udang vaname. Sampel yang digunakan adalah udang vaname sebanyak 10.000 ekor stadia juvenil. Pakan yang digunakan adalah pakan komersial yang ditambahkan crude protein Zoothamnium penaei dengan dosis $150 \mu$ l/ekor, yang diberikan sebanyak 7 kali berselang tiap 7 hari sejak umur 1 hari sampai udang umur 56 hari budidaya.

Hasil penelitian menunjukkan terjadi peningkatan respons imun (peningkatan THC dan DHC) akibat pemberian pakan yang ditambahkan crude protein Zoothamnium penaei. Total Haemosit (THC) tertinggi terjadi pada udang yang diberi pakan dan ditambahkan crude protein yaitu $56,58 \times 10^{6} \mathrm{sel} / \mathrm{ml}$, dan terendah pada udang yang tidak diberi crude protein yaitu $23,57 \mathrm{x}$ $10^{6} \mathrm{sel} / \mathrm{ml}$. Differential Haemocyte Count $(D H C)$ tertinggi juga terjadi pada udang yang diberi pakan dan ditambahkan crude protein, yaitu 26,57\% umur 60 hari dan terendah $14,99 \%$ pada udang tidak diberi crude protein umur 90 hari. Laju pertumbuhan spesifik tertinggi juga terjadi pada udang dengan pakan dan ditambahkan crude protein Zoothamnium penaei tertinggi yaitu $53,46 \%$ dan terendah $16,15 \%$ pada udang umur 90 hari. Kelulushidupan udang tertinggi terjadi pada udang dengan pakan dan ditambahkan crude protein Zoothamnium penaei umur 90 hari dengan kecenderungan lebih tinggi dari pada yang tidak diberi crude protein yaitu $72 \%$ dan $21 \%$.

Penambahan crude protein Zoothamnium penaei pada pakan komersial sebagai bahan imunostimulan dapat meningkatkan respon imun, pertumbuhan spesifik dan kelulushidupan udang vaname umur 30, 60 dan 90 hari di tambak, sehingga dapat dikembangkan sebagai bahan imunostimulan.
\end{abstract}

Kata kunci: Zoothamnium penaei, crude protein, udang vaname 


\begin{abstract}
The main obstacle in the aquaculture of vaname shrimp is the emergence of disease attacks that can cause death to $100 \%$ after 2 to 3 days after infection,. The purpose of this study was to analyze the immune response, specific growth rate and survival rate of vaname shrimp. The research method used was experimental to know the effect of feed use and added crude protein Zoothamnium penaei on vaname shrimp. The samples used were vanamei shrimp (Lithopenaeus vannamei) as many as 10,000 juvenile stadia. The feed used is commercial feed added with crude protein Zoothamnium penaei with dose $150 \mu \mathrm{l} /$ ekor, which is given 7 times intermittent every 7 days since 1 day until shrimp age 56 days aquaculture in pond. The results showed that there was an increase of immune response (increase of THC and DHC) due to feeding added by crude protein Zoothamnium penaei. Total Haemocytes (THC) was highest in commercial shrimps feed and added crude protein, $56.58 \times 106$ cells / ml, and the lowest in shrimp that is not given crude protein that is 23,57 x 106 cell / ml. Similarly, the highest Haemocyte Count (DHC) occurs in commercial shrimps feed and added crude protein, $26.57 \%$ age 60 days in ponds and 14.99\% low on shrimp not given crude protein age 90 day aquaculture. The highest specific growth rate of vaname shrimp also occurred in shrimp with commercial feed and added crude protein Zoothamnium penaei highest of $53.46 \%$ and the lowest $16.15 \%$ in shrimps age 90 days. The highest survival rate occurred also in shrimp with commercial feed and added crude protein Zoothamnium penaei after 90 day which has a higher tendency than shrimp withouth added crude protein that is $72 \%$ and $21 \%$. The addition of crude protein Zoothamnium penaei to commercial shrimp feed as immunostimulant material may enhance immune response, specific growth and survival rate of 30,60 and 90 days of shrimp aquaculture, so that it can be developed as an immunostimulant material.
\end{abstract}

Keyword: Zoothamnium penaei, crude protein, vanname shrimp

\section{PENDAhULUAN}

Kebijakan Pemerintah untuk mengembangkan budidaya udang vaname (Litopenaeus vannamei) di Indonesia pada tahun 2002, membawa dampak positif adanya peningkatan nilai ekspor udang yang mencapai 6 juta dolar Amerika (Departemen Kelautan Perikanan, 2005). Sebelum dikembangkan di Indonesia produksi udang nasional mengalami penurunan dari tahun ke tahun yang disebabkan karena adanya serangan penyakit dan menurunnya kualitas air di area pertambakan. Udang vaname (Litopenaeus vannamei) merupakan salah satu spesies udang yang diimpor dari Amerika Latin dan mulai masuk ke
Indonesia sejak tahun 1998. Harapan dari Pemerintah bahwa dengan memasukkan udang vaname ke Indonesia adalah dapat digunakan untuk menggantikan kedudukan udang windu (Penaeus monodon Fab).

Berbagai kendala utama dalam budidaya udang vaname yang perlu mendapat perhatian dan penanganan serius adalah adanya serangan penyakit yang muncul secara mendadak dan dapat menyebabkan kematian udang hingga mencapai $100 \%$ dalam waktu yang singkat antara 2-3 hari pasca infeksi (Kementerian Kelautan dan Perikanan, 2013). Kendala utama budidaya udang akibat serangan penyakit, pada udang vaname dapat disebabkan oleh parasit, bakteri, virus 
maupun jamur (Departemen Kelautan dan Perikanan, 2003). Beberapa penyakit dapat menyebabkan kematian udang pada berbagai stadia, baik pada saat budidaya di tambak maupun pada tahap pembenihan (Mahasri, 2007). Salah satu penyakit parasiter yang sering menyerang udang vaname di tambak dan pembenihan adalah zoothamniosis (Departemen Kelautan dan Perikanan, 2005), yaitu penyakit parasiter pada udang yang disebabkan oleh serangan Zoothamnium penaei. Penyakit ini dapat menyebabkan kematian pada tahap benih hingga $86 \%$. Kejadian zoothamniosis pada udang di Indonesia baik pada saat pembenihan maupun budidaya di tambak masih menunjukkan angka yang tinggi, sehingga perlu mendapat perhatian yang serius. Menurut Sumawidjaja (1991), kejadian zoothamniosis di pantai utara dan selatan Jawa Barat mencapai $85 \%$. Sindermann (1997) menemukan bahwa infestasi Zoothamnium penaei pada kolam dengan kadar oksigen rendah ( $<3 \mathrm{ppm})$ mencapai $80 \%$, sedangkan tingkat kejadian zoothamniosis di China meningkat dari tahun ke tahun yang dipengaruhi oleh faktor musim. Kejadian zoothamniosis meningkat pada saat musim panas, berkisar padan bulan Agustus sampai dengan bulan Oktober (Xiaozhong dan Song, 2000).

Upaya untuk mencegah zoothamniosis dapat dilakukan antara lain dengan pemberian pakan yang berkualitas serta penambahan imunostimulan. Raa (2002) menyatakan bahwa upaya untuk meningkatkan ketahanan tubuh udang baik pada tahap pembenihan maupun pemeliharaan di tambak dapat dilakukan dengan menggunakan imunostimulan, akan tetapi hingga saat ini belum dapat dikatakan berhasil sesuai dengan target. Supamattaya, et al. (1994) menyatakan bahwa sistem imun selular dan humoral pada udang berfungsi secara sinergistikal untuk melindungi udang dan menghilangkan patogen yang masuk ke dalam tubuh udang. Upaya pencegahan secara laboratoris terhadap zoothamniosis pada udang windu dengan imunostimulan protein membran imunogenik Zoothamnium penaei sudah dilakukan oleh Mahasri (2007). Hasil yang dilaporkan menunjukkan bahwa imunostimulan tersebut dapat meningkatkan pertahanan tubuh udang windu dan dapat meningkatkan kelangsungan hidup udang windu hingga $86 \%$.

Berbagai bahan sudah mulai dikembangkan untuk imunostimulan pada udang dengan memanfaatkan bagian-bagian dari pathogen, mikro dan makro alga. Aksono (2006) telah berhasil mengembangkan bahan sub unit vaksin untuk udang dari protein kapsid VP 28. Imunostimulan ini dapat menurunkan infeksi White Spot Syndrome Virus (WSSV) dan bersifat protektif pada udang. Kemudian Syafira (1998), menggunakan dinding sel bakteri untuk meningkatkan pertahanan tubuh udang dan hasilnya dapat meningkatkan aktivitas fagositosis dan kelulushidupan udang. Selanjutnya Mahasri (2007) juga sudah berhasil mengembangkan protein membran imunogenik Zoothamnium penaeiyang terbukti dapat meningkatkan aktivitas sel-sel pertahanan tubuh dan dapat melindungi benih udang windu. Selanjutnya dinyatakan bahwa imunostimulan tersebut dapat meningkatkan kelulushidupan dari 26\% menjadi 83\%. Gustrifandi (2012) melakukan uji coba budidaya udang di tambak yang sebelumnya diimunisasi secara dipping yang hasilnya dapat meningkatkan pertahanan tubuh udang vaname serta menurunkan infestasi Zoothamnium penaei.

\section{UDANG VANAME (Litopenaeus vannamei)}

Klasifikasi udang vaname (Litopenaeus vannamei) menurut Weyban dan Sweeney (1991) adalah sebagai berikut:
Filum : Arthropoda
Kelas : Crustacea
Sub kelas : Malacostraca
Ordo : Decapoda
Sub ordo : Dendrobrachiata
Famili : Penaeidae
Genus : Penaeus 
Sub genus : Litopenaeus

Spesies : Litopenaeus vannamei

Ciri morfologi yang membedakan udang vaname (Litopenaeus vannamei) dengan jenis udang lainnya adalah duri suporbital pada fase kedua dan ketiga protozoea (Haliman dan Adijaya, 2005). Bagian terbesar dari cepalothorax diisi oleh hepatopankreas yang berfungsi untuk menyerap nutrien, menyimpan lemak dan menghasilkan enzym pencernaan. Selain itu terdapat limfoid yang berfungsi untuk menyaring haemolym dan jaringan hematopoetik yang berfungsi untuk memproduksi haemocyte (Van de Braak, 2002).

Bagian kepala udang vaname terdiri dari antenula, antena, mandibula dan dua pasang maxillae. Selain itu juga terdapat tiga pasang maxilliped dan lima pasang kaki jalan (peripoda) atau kaki sepuluh (decapoda). Maxilliped sudah mengalami modifikasi dan berfungsi sebagai organ untuk pencernaan. Bagian abdomen terdiri dari 6 ruas. Pada bagian ini terdapat lima pasang kaki renang dan sepasang uropods (seperti ekor) yang membentuk kipas bersama-sama telson (Haliman dan Adijaya, 2005).

\subsection{Perkembangan Budidaya Udang Vaname}

Udang vaname memiliki pertumbuhan yang cepat, relatif tahan terhadap penyakit dan memiliki toleransi tinggi terhadap perubahan kondisi lingkungan (Widodo dan Dian, 2005). Dinyatakan juga bahwa pertumbuhan udang vaname lebih cepat dibandingkan dengan udang windu dan udang stylorostris (3 gram/minggu) dan dengan padat tebar tinggi hingga 150 ekor $/ \mathrm{m}^{2}$ (Briggs et al., 2004). Selain itu udang vaname tahan pada kisaran salinitas yang lebar (0,5-45 ppt) dengan kebutuhan protein pakan lebih rendah yaitu 20-35\% serta mampu mengkonversi pakan lebih baik (FCR 1,2-1,6).

Litopenaeus vannamei mempunyai toleran pada kadar salinitas 0,5 - $45 \mathrm{ppt}$ dengan salinitas optimal pada 7-34 ppt, akan tetapi dapat tumbuh dengan baik juga pada salinitas rendah yaitu kisaran 10-15 ppt (Wyban dan Sweedy, 1991). Kondisi ini menjadikan udang vaname sebagai kandidat yang baik bagi budidaya di daerah pedalaman Asia dan Amerika Latin dalam beberapa tahun terakhir. Suhu yang diperlukan bagi pertumbuhan optimal untuk udang vaname berkisar pada $23-30^{\circ} \mathrm{C}$ dan bisa mentoleransi perubahan suhu pada 15 $33^{\circ} \mathrm{C}$ (Wyban dan Sweeny, 1991). Namun demikian, pengalaman pada beberapa waktu belakangan ini, di Thailand, Ekuador dan beberapa tempat lain telah menunjukkan bahwa pada saat terjadi penurunan suhu air dibawah $\quad 30^{\circ} \mathrm{C}$ diiringi terjadinya peningkatan masalah dengan virus seperti WSSV dan TSV dan terjadi tidak hanya pada udang Penaeus monodon akan tetapi juga pada Litopenaeus vannamei.

\subsection{Pemberian Imunostimulan pada Udang}

Menurut Raa (2000) imunostimulan merupakan suatu bahan kimia yang dapat mengaktifkan sel darah putih (leukosit), sehingga organisme lebih tahan terhadap infeksi penyakit baik virus, bakteri, jamur dan parasite, sedangkan imunisasi adalah proses memasukkan bahan kimia dimaksud diatas ke dalam tubuh udang dengan tujuan yang sama yaitu bias mengaktifkan sel darah putih (leukosit).

Imunisasi pada udang merupakan suatu usaha untuk meningkatkan ketahanan tubuh udang dengan jalan memasukkan antigen ke dalam tubuh yang selanjutnya juga dikenal dengan vaksinasi (Anderson, 1995). Imunostimulan yang masuk ke dalam tubuh udang akan merangsang haemosit untuk melakukan degranulasi dan akan melepaskan protein seperti bindingmolecule $(\beta$ Glucan-binding protein / $\beta \quad G-B P$, Lipopolysaccaride-binding protein / LPS$B P$, Peptidoglycan-binding protein / $P G$ $B P)$ coagulation factors (transglutaminase), prophenoloxide related factors 
Jurnal Biosains Pascasarjana Vol. 19 (2017) pp (C) (2017) Sekolah Pascasarjana Universitas Airlangga, Indonesia

(prophenoloxide activating enzyme,

prophenoloxide, peroxinectin), protein 
inhibitors ( $\grave{\alpha}_{2}$ macroglobulin) dan anti microbial substances (penaedin, lectin). Beberapa protein yang dilepas tersebut akan digunakan untuk kepentingan respon imun seperti; phagocytosis, encapsulation,melanization, coagulation, aktifitas enzim prophenoloxidase, opsonisasi, aktivasi mikroba serta proses aktivitas humoral dan seluler lain (Soderhall et al., 1998 ; Van de Braak et al., 2000).

Pemberian imunostimulan pada udang tidak mempunyai efek samping dan sangat baik untuk diterapkan pada organisme yang tidak mempunyai sel memori dalam sistem imunnya sehingga dapat merangsang atau memaksimalkan respon imun non spesifik (Kwang, 1996). Vaksinasi dengan menggunakan bahan protein antigenik (imunogenik) masih belum banyak dilakukan. Menurut Mahasri (2007) dalam hasil penelitiannya dinyatakan bahwa protein membrane imunogenik Zothamnium penaei dapat memberikan proteksi pada udang windu dan berhasil meningkatkan aktivasi sel hemosit, sehingga meningkatkan tingkat kelulushidupan dari $21 \%$ menjadi $86 \%$ pada udang windu berumur 60 hari masa pemeliharaan di tambak.

\section{METODE PENELITIAN}

Metode dari penelitian ini adalah eksperimental yang dirancang sesuai dengan kondisi alami dari lingkungan, untuk menganalisis penggunaan pakan yang diberi bahan dari crude protein Zoothamnium penaei, terhadap laju pertumbuhan (growth rate), respon imun dan kelulushidupan (survival rate) udang vaname yang dibudidaya di tambak.

\subsection{Bahan dan Peralatan Penelitian}

Bahan yang digunakan pada penelitian ini adalah pakan buatan komersial yang beredar di pasaran, bahan imunostimulan yang digunakan dari crude protein Zoothamnium penaei, yang sudah diuji secara laboratoris dengan cara dipping dan secara laboratoris dengan cara oral oleh 
Darwatin (2016). Udang vaname sehat stadia jouvenil berumur 30 hari di dapat dari tambak pengelondongan milik Haji Syukri yaitu dari Wilayah Kecamatan Manyar, Kabupaten Gresik. Sedangkan bahan untuk pemeriksaan dan penghitungan THC dan DHC; adalah EDTA, methanol dan Giemsa.

Tambak dan sarana produksi yang digunakan dalam penelitian ini adalah milik Haji Kasum Abdullah di Desa Tlocor, Sidoarjo, sebanyak 3 petak yang masingmasing berukuran 1000 meter persegi. Alat untuk menghitung laju pertumbuhan adalah timbangan digital untuk mengukur berat udang dan penggaris berskala untuk mengukur panjang udang. Peralatan untuk menganalisis $T H C$ dan $D H C$ adalah; staining jare, spuit $1 \mathrm{ml}$, mikroskop dengan perbesaran 1000x serta haeositometer dan minyak emersi. Peralatan untuk mengukur kualitas air meliputi; thermometer untuk mengukur suhu air, refraktometer untuk mengukur salinitas, $\mathrm{pH}$ meter untuk mengukur $\mathrm{pH}$, DO-meter untuk mengukur oksigen terlarut dan tes kit untuk mengukur $\mathrm{NH} 3$ dan alkalinitas.

\subsection{Populasi dan Besar Sampel}

Populasi pada penelitian ini adalah populasi udang vaname yang diberi pakan buatan yang dicampur bahan dari crude protein Zoothamnium penaei dan dipelihara di tambak selama 3 bulan ( \pm 90 hari). Sampel dalam penelitian ini yaitu udang vaname dipelihara di tambak dan diberi pakan buatan yang dicampur bahan dari crude protein Zoothamnium penaei yang disampling pada hari ke 1, 30, 60 dan 90 hari.

Sampel berupa udang vaname berumur 1,30,60 dan 90 hari yang dipelihara di tambak diambil sebanyak 30 ekor setiap kali pengambilan (Cameron, 2002). Pengambilan sampel dilakukan secara acak pada setiap petak menggunakan anco. Sampel udang kondisi hidup dibawa ke Laboratorium Basah Fakultas Perikanan dan Kelautan.

\subsection{Variabel Penelitian}


Variabel dalam penelitian ini terdiri dari variabel bebas, tergantung dan kendali. Variabel bebas yaitu; dosis bahan imunostimulan dari crude protein Zoothamnium penaei yang diberikan pada pakan buatan. Variabel tergantung adalah laju pertumbuhan (Growth rate), respon imun Total Haemocyte Count (THC), DifferentialHaemocyte Count (DHC) dan kelulushidupan (Survival rate). Variabel kendali yaitu benur udang vaname stadia juvenil berumur 30 hari dengan berat $2-2,5$ gram, tambak, kualitas air dan pakan udang.

\subsection{Pelaksanaan Penelitian}

\subsubsection{Persiapan Tambak Pemeliharaan}

\section{Udang}

Persiapan tambak yang dilakukan meliputi pembersihan pelataran dalam tambak, penutupan tanggul yang sudah porus serta perbaikan saluran air. Kemudian dilakukan pengeringan, pengapuran menggunakan kapur $\mathrm{CaCO}_{3}$ (kapur pertanian) dan pemupukan dengan urea dan TSP dengan dosis $200 \mathrm{~kg}$ dan $100 \mathrm{~kg}$ per hektar dan dibiarkan selama 4 hari. Setelah itu dilakukan pengisian air sampai dengan kedalaman 1,5 meter dan dibairkan selama 1 minggu.

\subsubsection{Penyediaan Pakan Buatan diberi Bahan Imunostimulan}

Pakan yang digunakan pada penelitian ini adalah pakan udang vaname yang beredar secara umum di pasaran dengan cara mengambil beberapa sampel pakan yang ada di pasar, dianalisis proksimat untuk mendapatkan pakan yang kebutuhan nutrisinya sesuai dengan kebutuhan untuk udang vaname. Dari hasil analisis proksimat ditetapkan satu jenis pakan terpilih sebagai pakan yang digunakan dalam penelitian ini. Bahan imunostimulan yang digunakan dalam penelitian ini adalah bahan dari crude protein Zoothamnium penaei yang sudah diproduksi dan dievaluasi penggunaannya serta terbukti dapat 
Jurnal Biosains Pascasarjana Vol. 19 (2017) pp

(C) (2017) Sekolah Pascasarjana Universitas Airlangga, Indonesia

meningkatkan respon imun dan kelulushidupan udang oleh Mahasri (2007) dan Harijanto (2012) secara laboratoris.

Pakan yang sudah dipilih tersebut ditambahkan crude protein Zoothamnium penaei sebagai bahan imunostimulan 150 $\mu$ l/ekor. Bahan imunostimulan ini dicampurkan dalam pakan dengan perekat dari "progol" dengan disemprotkan pada pakan dan dikeringkan dengan cara dianginangin sampai kering. Setelah kering, pakan disimpan di tempat yang kering dan tidak lembab.

\subsubsection{Pelaksanaan Pemeliharaan Udang Vaname di Tambak}

Penelitian ini menggunakan 3 petak tambak ukuran masing-masing $1000 \mathrm{~m}^{2}$ yaitu :

Tambak I : Padat tebar udang vaname 5.000 ekor, dipelihara dan diberi pakan buatan yang dicampur bahan imunostimulan dari crude protein Zoothamnium penaei

Tambak II : Padat tebar udang vaname 5.000 ekor, dipelihara dan diberi pakan buatan tanpa diberi bahan imunostimulan dari crude protein Zoothamnium penaei

Tambak III : Petak tandon sebagai tempat pengendapan dan filter biologis

Pemeliharaan dilakukan selama 90 hari, hari pertama (ke satu) pada saat penebaran, udang diukur panjang dan beratnya, dengan teknologi budidaya udang vaname pola semi intensif menurut Haliman dan Adijaya (2005). Pakan buatan diberikan sebanyak 3 kali sehari dengan waktu pemberian pakan pada jam $09.00 ; 13.00$ dan 16.00. Sedangkan pemberian pakan yang diberi bahan imunostimulan dari crude protein Zoothamnium penaei adalah pada hari pertama pemeliharaan, yaitu satu kali pemberian sehari, selanjutnya dengan interval waktu pemberian pakan yang dicampur bahan imunostimulan setiap 7 hari sekali, satu kali pemberian sehari, sampai dengan pemeliharaan udang berumur 60 
hari, yaitu selama masa udang muda (juvenil). Pemberian pakan dilakukan dengan menggunakan anco sebanyak 5 titik anco pada tiap petakan.

\subsection{Parameter Penelitian}

Parameter utama dari penelitian ini adalah laju pertumbuhan spesifik, respon imun $T H C$ dan $D H C$ pada umur 30, 60 dan 90 hari di tambak, serta kelulushidupan udang vaname yang dipelihara dengan pemberian pakan yang diberi tambahan crude protein Zoothamnium penaei pada saat umur 90 hari di tambak.

Parameter pendukung dari penelitian ini adalah parameter kualitas air, yaitu ; suhu, kecerahan, salinitas, Dissolved Oxygen (DO), $\mathrm{pH}$, alkalinitas dan amoniak.

\subsection{Analisa Data}

Data yang terkumpul dianalisis secara deskriptif yaitu dengan tabel dan gambar serta dilakukan penjelasan terhadap data tersebut (Steel and Torrie, 1992).

\section{HASIL DAN PEMBAHASAN}

\subsection{Hasil}

\subsubsection{Respon Imun ( $T H C$ dan $\mathrm{DHC})$ Udang Vaname}

Pemeriksaan respon imun benih (Glondongan / PL 30) yang ditebar tidak dapat dilakukan, karena benih masih terlalu kecil dan mengalami kesulitan dalam pengambilan darah. Tabel 5.1 menunjukkan bahwa hasil penghitungan Total haemocyte Count (THC) udang vaname yang diberi pakan dan ditambahkan crude protein Zoothamnium penaei pada saat umur 30, 60 dan 90 hari di tambak. THC tertinggi ditemukan pada udang yang diberi pakan yang ditambahkan crude protein Zoothamnium penaei yang berumur 60 hari yaitu 56,58 x $10^{6} \mathrm{Sel} / \mathrm{ml}$, sedangkan terendah terjadi pada udang umur 30 hari, yaitu $27,57 \times 10^{6} \mathrm{Sel} / \mathrm{ml}$.
Tabel 5.1. Hasil Penentuan Total Haemocyte Count (THC) pada Udang Vaname

\begin{tabular}{|c|c|c|}
\hline \multirow{2}{*}{$\begin{array}{l}\text { Umur } \\
\text { Pemeliha } \\
\text { raan } \\
\text { (Hari) }\end{array}$} & \multicolumn{2}{|c|}{$\begin{array}{c}\text { Total Haemocyte Count } \\
\text { (THC) Udang } \\
\left(10^{6} \mathrm{Sel} / \mathrm{ml}\right)\end{array}$} \\
\hline & $\begin{array}{l}\text { Diberi pakan } \\
\text { yang tidak } \\
\text { ditambahkan } \\
\text { crude protein } \\
\text { Zoothamnium } \\
\text { penaei }\end{array}$ & $\begin{array}{c}\text { Diberi pakan } \\
\text { yang } \\
\text { ditambahkan } \\
\text { crude protein } \\
\text { Zoothamnium } \\
\text { penaei }\end{array}$ \\
\hline 30 & 27,57 & 41,64 \\
\hline 60 & 28,58 & 56,58 \\
\hline 90 & 29,58 & 43,75 \\
\hline
\end{tabular}

Hasil penghitungan $\mathrm{DHC}$ udang vaname yang diberi pakan dan ditambahkan crude protein Zoothamnium penaei maupun tidak ditambahkan crude protein Zoothamnium penaei dapat dilihat pada Tabel 5.2. Tabel 5.2 menunjukkan bahwa penambahan crude protein Zoothamnium penaei memberikan perubahan pada respon imun udang vaname $(D H C)$.

Tabel 5.2. Hasil Penentuan Differensial Haemocyte Count (DHC) pada Udang Vaname

\begin{tabular}{|c|c|c|}
\hline \multirow{2}{*}{$\begin{array}{c}\text { Umur } \\
\text { pemeliha } \\
\text { raan } \\
\text { (Hari) }\end{array}$} & \multicolumn{2}{|c|}{$\begin{array}{c}\text { Differential Haemocyte Count } \\
(D H C) \text { Udang }(\%)\end{array}$} \\
\hline & $\begin{array}{l}\text { Diberi pakan } \\
\text { yang tidak } \\
\text { ditambahkan } \\
\text { crude protein } \\
\text { Zoothamnium } \\
\text { penaei }\end{array}$ & $\begin{array}{l}\text { Diberi pakan } \\
\text { yang } \\
\text { ditambahkan } \\
\text { crude protein } \\
\text { Zoothamnium } \\
\text { penaei }\end{array}$ \\
\hline 30 & 15,59 & 17,78 \\
\hline 60 & 16,50 & 26,57 \\
\hline 90 & 14,99 & 24,03 \\
\hline
\end{tabular}

\subsubsection{Laju Pertumbuhan Spesifik Udang Vaname}

Hasil penghitungan menunjukkan bahwa laju pertumbuhan udang vaname dapat dilihat pada Lampiran 1. Rata-rata nilai laju pertumbuhan udang vaname yang diberi pakan berturut-turut umur 30, 60 dan 
Jurnal Biosains Pascasarjana Vol. 19 (2017) pp (C) (2017) Sekolah Pascasarjana Universitas Airlangga, Indonesia

90 hari dapat dilihat pada Tabel 5.3. Laju 
pertumbuhan tertinggi terjadi pada udang vaname yang diberi pakan dan ditambahkan crude protein Zoothamnium penaei.

Tabel 5.3. Rata-rata Laju Pertumbuhan Udang pada Berbagai Perlakuan

\begin{tabular}{c|c|c}
\hline \multirow{2}{*}{ Umur } & \multicolumn{2}{|c}{$\begin{array}{c}\text { Laju pertumbuhan spesifik udang } \\
\text { vaname (\%) }\end{array}$} \\
\cline { 2 - 3 } & $\begin{array}{c}\text { Diberi pakan } \\
\text { yang tidak } \\
\text { ditambahkan } \\
\text { crude protein } \\
\text { Zoothamnium } \\
\text { penaei }\end{array}$ & $\begin{array}{c}\text { Diberi pakan } \\
\text { yang } \\
\text { ditambahkan } \\
\text { crude protein } \\
\text { Zoothamnium } \\
\text { penaei }\end{array}$ \\
\hline 30 & 42,23 & 53,46 \\
\hline 60 & 24,28 & 44,12 \\
\hline 90 & 16,15 & 24,15 \\
\hline
\end{tabular}

Tabel 5.3 menunjukkan bahwa laju pertumbuhan udang vaname yang diberi pakan dan ditambahkan crude protein Zoothamnium penaei lebih besar jika dibandingkan dengan yang tidak ditambahkan crude protein Zoothamnium penaei tiap masa pemeliharaan. Laju pertumbuhan udang vaname tertingggi adalah pada udang yang ditambahkan crude protein Zoothamnium penaei $53,46 \%$ pada udang umur 30 hari di tambak. Kemudian diikuti berturut-turut pada umur 60 dan 90 hari di tambak yaitu $44,12 \%$ dan $24,15 \%$. Sedangkan laju pertumbuhan udang vaname yang diberi pakan dan tidak ditambahkan crude protein Zoothamnium penaei berturut-turut $42,23 \% ; 24,28 \%$ dan $16,15 \%$ pada umur 30, 60 dan 90 hari di tambak.

\subsubsection{Penentuan Tingkat Kelulushidupan (SR) Udang Vaname}

Hasil penentuan tingkat kelulushidupan udang vaname dapat dilihat pada Tabel 5.4.

Tabel 5.4. Hasil Penentuan Tingkat Kelulus hidupan Udang Vaname

\begin{tabular}{c|c}
\hline Perlakuan & $\begin{array}{c}\text { Tingkat } \\
\text { kelulushidupan } \\
(\%)\end{array}$ \\
\hline Pakan tidak diberi & \\
\hline
\end{tabular}

\begin{tabular}{l|c}
\hline & \\
\hline $\begin{array}{l}\text { Zoothamnium penaei } \\
\text { Pakan diberi crude } \\
\text { protein Zoothamnium }\end{array}$ & 72 \\
\hline penael
\end{tabular}

Kelulushidupan udang vaname pada umur 90 hari budidaya di tambak (saat panen) yang diberi pakan ditambahkan crude protein Zoothamnium penaei mencapai $72 \%$, lebih tinggi dari pada yang diberi pakan dan tidak ditambahkan crude protein Zoothamnium penaei yang mencapai $21 \%$ pada akhir masa budidaya yaitu 90 hari.

\subsubsection{Pemeriksaan Kualitas Air}

Hasil pemeriksaan kualitas air selama 90 hari masa pemeliharaan dapat dilihat pada tabel 5.5.

Tabel 5.5. Hasil Rata-Rata Pemeriksaan Kualitas Air Tambak selama 90 Hari Masa Pemeliharaan

\begin{tabular}{l|c|c}
\hline Parameter & $\begin{array}{c}\text { Rata-rata } \\
\text { parameter } \\
\text { /kualitas air } \\
\text { selama } \\
\text { pemelihara } \\
\text { an }\end{array}$ & $\begin{array}{c}\text { Kisaran } \\
\text { nilai } \\
\text { normal }\end{array}$ \\
\hline Suhu $\left({ }^{\circ} \mathrm{C}\right)$ & $28-29$ & $27-32$ \\
\hline Salinitas (\%oo $)$ & $26-26$ & $16-30$ \\
\hline pH & $7,8-8,4$ & $7,5-8,5$ \\
\hline $\begin{array}{l}\text { Oksigen } \\
\text { Terlarut ( ppm })\end{array}$ & $3,5-6,6$ & $>3-7$ \\
\hline $\begin{array}{c}\text { Amoniak } \\
(\text { ppm })\end{array}$ & $0.09-0,1$ & $<1$ \\
\hline
\end{tabular}

Hasil pengukuran menunjukkan bahwa kualitas air tambak selama 90 hari masa pemeliharaan udang vaname rata-rata masih dalam kisaran normal, sehingga sesuai dengan persyaratan pemeliharaan udang vaname.

\subsection{Pembahasan}

Hasil penelitian menunjukkan bahwa pemberian pakan yang ditambahkan 
Jurnal Biosains Pascasarjana Vol. 19 (2017) pp (C) (2017) Sekolah Pascasarjana Universitas Airlangga, Indonesia

crude protein

21

dengan crude protein Zoothamnium penaei 
dapat meningkatkan respon imun dilihat dari kenaikan $T H C$ dan $D H C$ dan kelulushidupan udang .

Tabel 5.1 menunjukkan bahwa respon imun ( $T H C$ dan $D H C$ ) udang vaname yang diberi pakan dan ditambahkan crude protein Zoothamnium penaei terjadi peningkatkan dan mulai hari ke 30 pemeliharaan yaitu dari $27,57 \times 10^{6} \mathrm{se} / \mathrm{ml}$ menjadi $41,64 \times 10^{6} \mathrm{se} / \mathrm{ml}$. Sedangkan pada umur udang 60 hari THC udang mengalami peningkatan dari $28,58 \times 10^{6} \mathrm{se} / \mathrm{ml}$ menjadi $56,58 \times 10^{6} \mathrm{se} / \mathrm{ml}$ dan pada umur 90 hari meningkat dari $29,58 \times 10^{6} \mathrm{se} / \mathrm{ml}$ menjadi $43,75 \times 10^{6} \mathrm{se} / \mathrm{ml}$. Tabel 5.1. secara keseluruhan menunjukkan bahwa udang vaname yang diberi pakan dan ditambahkan crude protein Zoothamnium penaei selalu terjadi peningkatan selama masa pemeliharaan 90 hari (panen). Sedangkan pada udang yang tidak ditambahkan crude protein Zoothamnium penaei menunjukkan bahwa THC meningkat hingga pada pemeliharaan hari ke 60, akan tetapi terjadi penurunan pada hari ke 90 dengan nilai yang berbeda, tetapi lebih tinggi pada udang yang diberi pakan dan ditambahkan crude protein Zoothamnium penaei. Tabel 5. 2 juga menunjukkan bahwa THC udang yang udang vaname yang diberi pakan dan ditambahkan crude protein Zoothamnium penaei meningkat sampai dengan pada hari ke 60 dan menurun pada hari ke 90 .

Hasil pengukuran $D H C$ udang vaname (Tabel 5.2) yang diberi pakan dan ditambahkan crude protein Zoothamnium penaei juga mengalami peningkatan dari $15,59 \%$ menjadi $17,78 \%$ pada udang umur 30 hari, dan dari $16,50 \%$ menjadi $26,57 \%$ pada udang umur 60 hari dan dari $14,99 \%$ menjadi $24,03 \%$ pada umur 90 hari. Tabel 5.2 juga menunjukkan bahwa $D H C$ udang vaname yang diberi pakan dan tidak ditambahkan crude protein Zoothamnium penaei juga mengalami peningkatan selama pemeliharaan yaitu $15,59 \%, 16,50 \%$ pada hari ke 30 dan 60, serta menurun hingga $14,99 \%$ dan 90 hari.

Terjadinya peningkatan respun imun baik $T H C$ maupun $D H C$, merupakan indikator bahwa pemberian pakan yang ditambahkan crude protein Zoothamnium penaei sebagai bahan imunostimulan juga dapat dilihat dari tingkat kelulushidupan udang vaname, yaitu antara $72 \%$ dan $21 \%$. Hal ini dapat diartikan bahwa crude protein tersebut mampu memberikan perlindungan (bersifat protektif) pada udang yang dipelihara di tambak terutama terhadap zoothamniosis. Crude protein Zoothamnium penaei sebagai bahan imunostimulan yang masuk ke tubuh udang akan merangsang aktifitas sel-sel haemosit pada udang, sebagai upaya untuk melawan patogen yang masuk dalam tubuh udang selama pemeliharaan. Hal ini sesuai dengan Van de Braak (2002) dalam Mahasri (2007) bahwa sel haemosit yang diaktifkan oleh imunostimulan akan melakukan aktifitas fagositik pada udang oleh sel hyalin (granular) dan semi granular.

Menurut Soderhall dan Cerenius (1992) yang menyatakan bahwa sistem kekebalan tubuh pada udang masih primitif dan tidak seperti pada ikan serta mamalia yang mempunyai imunoglobulin, sehingga imunoglobulin pada udang digantikan oleh Prophenoloxidase Activating Enzim (PPA). PPA tersebut merupakan protein yang berlokasi di sel granular hemosit. PPA ini dapat diaktifkan oleh lipopolisakarida dan $\beta$ 1,3-Glukan, yang akan merangsang prophenoloksidase menjadi phenoloksidase. Sebagai akibat dari perubahan ini akan dihasilkan semacam protein Opsonin Factor yang dapat menginduksi sel-sel hyalin untuk melakukan proses fagositosis. Van de Braak (2002) dan Smith, et al. (2003) juga mendukung pernyataan diatas bahwa sel haemosit tersebut akan melakukan degranulasi, dan beberapa protein akan dilepas untuk kepentingan respon imun, seperti : meningkatnya sel-sel haemosit, dan meningkatnya aktifitas penjeratan dan fagositosis. Di samping itu protein membran imunogenik akan merangsang haemosit untuk melepaskan proPO dan proteinbinding PPA, sehingga mengakibatkan sel haemosit meningkatkan aktifitasnya untuk melakukan penjeratan dan fagositosis 
terhadap agen penyakit yang dalam hal ini adalah Zoothamnium penaei.

Jika crude protein Zoothamnium penaei sebagai bahan imunostimulan tersebut masuk ke dalam tubuh udang maka akan menyebabkan meningkatnya jumlah haemosit $(T H C)$ dan diferensial sel haemosit $(D H C)$. Hal ini merupakan indikasi meningkatnya pertahanan tubuh udang vaname (Mahasri, 2007). Selanjutnya Itami et al. (1996) mendukung teori tersebut, yang mengatakan bahwa pemberian imunostimulan dapat mencegah infeksi penyakit dalam tubuh inang dan menyebabkan meningkatnya aktifitas fagosit haemosit dan enzim proPO. Pernyataan ini diperkuat oleh Soderhall, et al.(1996) dan Van de Braak (2002) bahwa bahan imunostimulan yang masuk ke dalam tubuh udang akan menimbulkan antibodi yang mampu menetralisir patogen, sehingga tidak dapat menginfeksi pada udang.

Menurut Mahasri (2007) bahwa protein membran imunogenik Zoothamnium penaei yang masuk ke dalam tubuh dapat meningkatkan kelangsungan hidup udang windu dari $17 \%$ hingga $68 \%$ pada udang umur 90 hari (akhir pemeliharaan). Selanjutnya juga dikatakan bahwa respon imun dari udang windu juga mengalami peningkatan yang ditandai dengan meningkatnya $T H C$ dan $D H C$, karena protein membran imunogenik Zoothamnium penaei mempunyai berat molekul yang besar yaitu lebih besar dari 1000 Dalton sehingga bersifat imunogenik. Protein yang mempunyai berat molekul yang tinggi, dan mempunyai tingkat imunogenitas yang tinggi, protein tersebut harus mempunyai struktur yang komplek. Menurut pendapat Tizard (1988) dan Baratawidjaja (2004) protein yang bersifat imunogenik mempunyai berat molekul yang besar lebih dari 1000 Dalton dan mempunyai struktur yang komplek.

Meningkatnya total sel haemosit (THC) dan DHC tersebut dapat digunakan sebagai indikator atau tanda adanya infeksi patogen pada tubuh inang. Infeksi ini akan menyebabkan inflamasi, yang merupakan karakteristik pertahanan tubuh non spesifik karena adanya faktor yang mempengaruhi seperti parasit, bakteri, jamur, virus dan agen tidak hidup (Soderhall dan Cerenius, 1992 dan Rengpipat et al., 2000). THC pada udang yang diberi pakan dan ditambahkan crude protein Zoothamnium penaei meningkat pada udang dari umur 30 hari sampai dengan 60 hari, akan tetapi menurun pada umur 90 hari. Hal ini disebabkan karena sistem kekebalan udang akan meningkat seiring dengan meningkatnya umur udang dan akan tetapi pada batas umur tertentu akan kembali menurun. Tingginya THC ini menunjukkan bahwa crude protein yang ditambahkan dapat meningkatkan respons imun udang, karena tingginya $T H C$ pada udang merupakan salah satu indikator meningkatnya ketahanan tubuh udang. Hal ini sesuai dengan pendapat Soderhall et al. (1992) yang mengatakan bahwa meningkatnya respons imun pada invertebrata ditunjukkan dengan adanya peningkatan THC. Peningkatan THC dan $D H C$ ini dapat digunakan indikasi adanya reaksi pertahanan tubuh udang dengan adanya infeksi oleh patogen. Terjadinya peningkatan yang nyata dari DHC (sel haemosit granular), diduga karena udang tidak mempunyai sel memori pada sistem kekebalan tubuh, sehingga tidak mampu mendeteksi bahan patogen yang pernah terpapar. Dengan demikian dapat dikemukakan bahwa crude protein ini dapat menginduksi mekanisme pertahanan tubuh udang. Akan tetapi membutuhkan waktu untuk merangsang organ hematopoetik agar memproduksi granulosit untuk melawan serangan patogen (Mahasri, 2007). Granulosit ini akan menghancurkan patogen dengan jalan menelan patogen tersebut, sehingga sel granulosit ini akan bermigrasi ke daerah-daerah yang mengalami infestasi parasit.

Di sisi lain kualitas air pemeliharaan juga berpengaruh pada infestasi dan respon imun pada udang, akan tetapi berdasarkan hasil penelitian, menunjukkan bahwa kualitas air dalam kondisi yang optimal bagi kehidupan udang. Kualitas air yang dalam 
kondisi baik tersebut akan menyebabkan patogen yang bersifat oportunistis tidak dapat menyebabkan sakit pada udang, sehingga udang dalam keadaan sehat dan sistem pertahanan tubuh udang tetap terjaga. Terjaganya kualitas air tersebut akan menyebabkan udang dapat hidup dengan baik dan meminimalkan munculnya serangan penyakit, sehingga udang dapat tumbuh dengan baik.

Tabel 5.3. menunjukkan bahwa laju pertumbuhan udang vaname yang diberi pakan dan ditambahkan crude protein Zoothamnium penaei selalu meningkat seiring dengan meningkatnya umur udang di tambak. Laju pertumbuhan udang pada hari ke 30 di tambak, menunjukkan laju pertumbuhan tertinggi yaitu sebesar 53,46\%, kemudian meningkat menjadi $44,12 \%$ pada umur 60 hari, dan menurun kembali pada umur ke 90 yaitu menjadi $24,15 \%$. Untuk laju pertumbuhan udang vaname yang diberi pakan dan tidak ditambahkan crude protein Zoothamnium penaei juga mengalami pertumbuhan yang meningkat seiring dengan umur udang di tambak, akan tetapi besar laju pertumbuhan tidak sebesar udang vaname yang diberi crude protein Zoothamnium penaei, berturut - turut dari umur 30, 60 dan 90 hari di tambak adalah $42,23 \% ; 24,28 \%$ dan $16,15 \%$. Hal ini sesuai dengan pendapat Tahe et al. (2009) dalam Suwoyo dan Mangampa (2010) yang mengatakan bahwa laju pertumbuhan spesifik yang tertinggi adalah pada udang 45 hari pemeliharaan di tambak kemudian $33,45 \%$, dan menurun pada masa pemeliharaan 60 hari di tambah yaitu sebesar $17,89 \%$. Hal ini menunjukkan bahwa pakan pada masing-masing perlakuan yang diberikan cukup untuk memenuhi kebutuhan hidup udang vaname. Peningkatan pertumbuhan ini dapat diketahui melalui peningkatan laju pertumbuhan dan laju pertumbuhan spesifik (Boeuf dan Payan, 2001)

Terjadinya pertumbuhan yang lebih besar pada udang vaname yang diberi pakan yang ditambahkan dengan crude protein Zoothamnium penaei disebabkan karena banyak faktor, yang dapat dibagi menjadi faktor internal dan eksternal. Faktor internal yang mempengaruhi pertumbuhan adalah jenis, ukuran, umur dan akitivitas fisiologis. Faktor lingkungan yang mempengaruhi pertumbuhan adalah oksigen, nitrogen, ammonia, suhu, daya racun dan kuantitas air. Faktor yang mempengaruhi pertumbuhan adalah tipe diet dan feeding level (Handajani dan Widodo, 2010). Laju pertumbuhan berhubungan dengan ketepatan antara jumlah pakan yang diberikan dengan kapasitas lambung dan kecepatan pengosongan lambung dan kecepatan pengosongan lambung atau sesuai dengan waktu ikan membutuhkan pakan, perlu diperhatikan karena pada saat itu ikan sudah dalam kondisi lapar (Sunarno, 1991 dalam Sari et al., 2009).

Pakan yang digunakan dalam penelitian ini adalah pakan buatan dengan kandungan protein kasar $(26,17 \%)$, lemak kasar $(8,85 \%)$ dan serat kasar $(6,26 \%)$ pada pakan lebih rendah jika dibandingkan dengan kebutuhan protein untuk udang vaname berturut-turut, yaitu $37,51 \%$, $13,11 \%$ dan $12,40 \%$ (Ryna and Medina, 2011). Rendahnya protein, lemak kasar dan serat kasar pada pakan yang digunakan akan mempengaruhi pertumbuhan udang. Akan tetapi laju pertumbuhan spesifik udang yang diberi pakan dan tidak ditambahkan crude protein Zoothamnium penaei menunjukkan nilai yang rendah pada semua tingkatan umur udang di tambak yaitu 30, 60 dan 90 hari. Sedangkan pertumbuhan spesifik udang yang diberi penambahan crude protein cenderung menunjukkan angka yang lebih tinggi. Rendahnya laju pertumbuhan udang vaname ini disebabkan karena nutrisi pakan yang diberikan masih terlalu rendah jika dibandingkan dengan kebutuhan nutrisi udang pada umumnya. Hal ini tidak sesuai dengan pendapat Heptarina, dkk. (2010) pakan dengan kadar protein yang lebih tinggi dari pakan yang diberikan yaitu $35 \%$, $15,20 \%$ lemak dan $5,31 \%$ serat kasar menghasilkan pertumbuhan udang vaname dan konversi pakan terbaik. Rendahnya kadar protein yang sesuai, kadar lemak yang 
tidak terlalu rendah menyebabkan udang mengkonsumsi pakan yang tidak cukup nutrisinya untuk pertumbuhannya.

Jika dikaitkan dengan tingkat kelulushidupan udang vaname, nampak bahwa udang yang diberi pakan yang ditambahkan crude protein Zoothamnium penaei mencapai $72 \%$ sedangkan yang tidak ditambahkan crude protein hanya mencapai $21 \%$. Hal ini menunjukkan bahwa crude protein yang diberikan dapat meningkatkan pertahanan tubuh udang dan dengan dukungan kualitas air yang baik selama penelitian menyebabkan udang dalam kondisi yang baik, yang dapat meningkatkan laju pertumbuhan udang.

\section{KESIMPULAN DAN SARAN}

Kesimpulan yang dapat diajukan dari hasil penelitian ini adalah sebagai berikut :

1. Pemberian pakan yang ditambahkan crude protein Zoothamnium penaei mampu meningkatkan respons imun (meningkatkan THC dan DHC) pada udang vaname yang dipelihara di tambak. Respon imun udang vaname meningkat sampai dengan umur 60 hari dan menurun kembali pada umur 90 hari di tambak danmasih dalam batas normal.

2. Pemberian pakan yang ditambahkan crude protein Zoothamnium penaei mampu meningkatkan laju pertumbuhan spesifik udang vaname selama 90 hari pemeliharaan di tambak

3. Pemberian pakan yang ditambahkan crude protein Zoothamnium penaei mampu mampu meningkatkan kelulushidupan udang vaname dari $21 \%$ hingga $72 \%$ selama 90 hari pemeliharaan di tambak

\subsection{Saran}

Saran yang dapat diajukan dari hasil penelitian adalah sebagai berikut :

1. Penelitian lebih lanjut diperlukan untuk mengetahui metode imunisasi yang tepat dan efektif dalam penggunaan imunostimulan dari crude protein Zothamnium penaei di lapangan (tambak).

2. Pemantauan kualitas air tetap harus dilakukan selama pemeliharaan udang di tambak untuk dapat mendukung pertumbuhan udang optimal.

\section{DAFTAR PUSTAKA}

Adiwidjaya, D., Supito dan I. Sumantri, 2008. Penerapan Budidaya Udang Vannamei (Litopenaeus vannamei) Semi Intensif pada Lokasi Tambak Salinitas Tinggi. Media Budidaya Air Payau Perekayasaan (7) : hal 5472.

Aiken, D. 1990. Shrimp Farming in Equator. World Aquaculture $21: 48-55$.

Ajiboye, E.A., Adedayo, M.R., Akintunde, J.K., Odaibo, A. 2012. Single Cell Protein : As Nutrition Enhancer. Advance in Applied Science Research. 2(5) : 396-409.

Anderson D.P. and Siwicki. 1995. Basic Haematology and Serology for Fish Health Programs. In Disease in Asian Aquaculture II. M. Shariff, J.R. Arthur, R.P. Subangsinghe 9Eds) Fish Health Section Asian Fisheries Society: 185-202.

Boyd, C.E. and Clay, J.W. 2002. Evaluation of Belize Aquaculture LTD, A Superintensive Shrimp Aquaculture System. Report prepared Under The World Bank, NACA and FAO Consorsium, Work in Progress for Public Discussion. Publised by The Consorsium.17p.

Briggs, M., Smith, S.F., Subasinghe, R., Phillips, M. 2004. Introduction and Movement of Penaeus vnnamei and 
Penaeus stylirostris in Asia and The Pacific. RAP Publication 2004/10.

Blaxhall, P. And K. Daisley. 1993. Some Blood Parameters of The Rainbow Trout I. The Kamloops Variety. J. Fish. Biol. 5: 1-8.

Chamratchakool P. 1996. Health Management in Shrimp Ponds, Health Research Institute, Bangkok, Thailand: 50-53.

Departemen Kelautan dan Perikanan. 2003. Jenis Penyakit Udang pada Budidaya Air Payau. Artikel 02/09/04. Mina Diklat BPPP Belawan Medan.

Departemen Kelautan dan Perikanan. 2005. Revitalisasi Budidaya Udang di Indonesia. Makalah disampaikan pada Pertemuan Teknis Petambak Udang se Jawa Timur, Surabaya 13 Februari 2005.

Foster C.A, Sharpie T.G and Hawkins W.E. 1998. Fine Structure og the Peritrichous Ectocomensal Zoothamnium sp, with Emphasis on Mode of Attachment to Penaeid Shrimp, Cool Fish University Washington, Seattle, W.A, 98195, USA, Fish Dis.: 1(4) : 321-335.

Gillet, J. 2008. Global Study of Shrimp Fisheries. Fisheries Technical Paper Food Agricultural Organization 475. Pp.107.

Gustrifandi, H. 2013. Prevalensi Zoothamnium penaei, Respon Imun dan Kelulushidupan pada Udang Vaname (Litopenaeus vannamei) di Tambak yang Diimunisasi dengan Protein Membran Imunogenik Zoothamnium penaei. Tesis, Program Pascasarjana, Universitas Airlangga.

Gunarto, Mansyur, A. dan Muliani. 2009. Aplikasi dosis fermentasi probiotik berbeda pada budidayaUdang vaname (Litopenaeus vannamei) pola intensif. Balai Riset Perikanan Budidaya Air Payau, Maros, Sulawesi Selatan.

Harijanto. 2012. Kemampuan Proteksi Imunostimulan dari Protein Membran Imunogenik Zoothamnium penaei Terhadap Zoothamniosis pada Udang Vanname (Litopenaeus vannamei), Tesis, Program Pascasarjana, Universitas Airlangga.

Heptarina, Deisi, dkk. 2010. Pengaruh Pemberian Pakan dengan Kadar Protein Berbeda Terhadap Pertumbuhan Yuwana Udang Putih Litopenaeus vannamei. Prosiding Forum Inovasi Teknologi Akuakultur. Balai Riset Perikanan Budidaya Air Tawar. Bogor : Institute Pertanian Bogor.

Herawati, Vivi Endar. 2005. Mengembangkan Program Kuliah Mata Kuliah Manajemen Pemberian Pakan Ikan. Fakultas Perikanan dan Ilmu Kelautan. Semarang : Universitas Diponegoro.

Itabashi T, Terasaki T and Asai H. 2004. Novel Nuclear and Cytoplasmic Proteins Detected by AntiZoothamnium arbuscula(Protozoa) Spasmin 1 Antibody In Mammalian Cells Are Dependent on The Cell Cycle, Biochem J.,136 (5) : 651657.

Itami, T. 1994. Body Defense System of Penaeid Shrimp, Seminar on Fish Physiology and Prevention of Epizootics, Department of Aquaculture and Biology, Shimmonoseki University of Fisheries, Japan, 7 : 59-65.

Itami T., Kondo M. And Takahasi Y. 1996. Enchancement of Disease Resistance of Kuruma Prawn, 
Penaeus japonicus After Oral Administration of Peptidoglucan, National Fisheries University, Japan, 7: 59-65.

Johanson M.W. and Soderhall K. 1989. Celluler Immunity in Crustacean and the Pro System, Parasitology Today, 5 (6) : 171-176.

Kementrian Kelautan dan Perikanan. 2013. Materi Penyuluhan Budidaya Udang Vanname (Litopenaeus vannamei). Pusat Penyuluhan Kelautan dan Perikanan.

Kwang, L.C. 1996. Immune Enhancer in the Control of Diseases in Aquaculture. Encap Technology Pte. Ltd. 14, Besut Street, Jurong Town, Singapore : 99-128.

Lightner. 1996. A Handbook of Shrimp Pathology and Diagnostic Procedures for Diseases of Cultured Penaeid Shrimp. World Aquaculture Society, Baton Rouge, Louisiana, USA.

Mahasri G. 1999. Perkembangan Jumlah Ciliata Patogen pada Udang Windu pada Padat Tebar dan Aerasi yang Berbeda, Media Kedokteran Hewan, Universitas Airlangga, 15:4.

Mahasri G. 2004. Efektivitas Ikan Bandeng sebagai Filter Biologi Menekan Zoothamniosis pada Budidaya Udang Windu Secara Intensif. Makalah disampaikan pada Seminar Nasional Review Tentang Perkembangan Ilmu Pengetahuan dan Teknology Perikanan, tanggal 30 Nopember 2004 di Semarang.

Mahasri G. 2007. Hubungan Kadar Oksigen Terlarut dengan Kejadian Zoothamniosis di Daerah Pertambakan Pantai Utara Jawa Timur. Karya Ilmiah Perikanan : $1: 1$.
Mahasri G. 2007. Protein Membran Imunogenik Zoothamnium penaei Sebagai Bahan Pengembangan Imunostimulan pada Udang Windu (Penaeus monodon Fab.) Terhadap Zoothamniosis. Disertasi. Universitas Airlangga.

Mahasri G. 2013. Buku Ajar Manajemen Kualitas Air Fakultas Perikanan dan Kelautan Universitas Airlangga. Global Persada. Surabaya.

Manoppo, H. 2011. Peningkatan Respons Imun Non-Spesifik, Resistensi, Dan Pertumbuhan Udang Vaname (Litopenaeus Vannamei) Melalui Pemberian Pakan Nukleotida. Departemen Budidaya Perairan, FPIK, Institut Pertanian Bogor.

Martin, G.G. and L.B. Graves. 1990. Fine Structure and Classification in Shrimp Haemocytes. J. Morfol, 85 : 339-348.

Nash, G.L., Anutara and W. Boonsirm. 1993. Rapid Diagnosis of Yellowhead Diseases in Black Tiger Shrimp Culture Research Centre. AHHRI NEWSLETTER, July 1993. Charoen Phokphand Feedmil Co. Ltd, Smuth Sakorn, Thailand. 87 pp.

Nuhman. 2009. Pengaruh Prosentase Pemberian Pakan Terhadap Kelangsungan Hidup dan Laju Pertumbuhan Udang Vannamei (Litopenaeus vannamei). Jurnal Ilmiah Perikanan dan Kelautan Vo. 1 No. 2. Surabaya : Universitas Hangtuah.

Owens L. and O’Neill A. 1997. Use of Clinical Cell Flow Cytometry for Differential Count of Prawn (Penaeus monodon) Haemocytes, Diseases of Aquatic Organisms, 31 : 147-153.

Pangkey, Henneke. 2011. Peranan Protein 
Jurnal Biosains Pascasarjana Vol. 19 (2017) pp (C) (2017) Sekolah Pascasarjana Universitas Airlangga, Indonesia

Untuk Budidaya Ikan Nila 
(Oreochromis niloticus). Warta Iptek, 37.pp.58-65. ISSN 08540667.

Raa, J. 2000. The Use of Immunostimulant in Fish and Shellfish Feeds, In : LE. Cruz Suarez, D. Richie-Marie, M. Tapia-Salazar, M.A. Olver-Novoa, R. Civera-Cerecedo, (Eds), Avences en Nutricion Acuicola, Merid, Yucatan, Ico : 47-54.

Ridlo, A. dan Pramesti, R. 2009. Aplikasi Ekstrak Rumput LautSebagai Agen Imunostimulan Sistem PertahananNon Spesifik Pada Udang (Litopennaeus vannamei). Penelitian DIKTI. Fakultas Perikanan dan Ilmu KelautanUniversitas Diponegoro, Semarang.

Roitt, I., Brostoff, J. And Male, D. 1998. Immunology 4th Ed. Barcelona, Spain, Mosby, Times Mirror International Publisher Limited.

Sindermann, C.J. 1997. Ciliata Infestation, Trans. Am. Microse.Soc. 98 (1) : 136-138.

Smith V.J., Brown J.H. and Hauton C. 2003. Immunostimulation in Crustaceans : does it Really Protect Againts Infection?, Fish and Shellfish Immunology, $15: 71-90$.

Soderhall, K. 1998. Role of the Prophenolokxidase Activating System in Invertebrates Immunity, Current Opinion in Immunology, 10 :23-28.

Subaidah Siti, dkk. 2010. Perbaikan Nutrisi Induk Udang Vanname (Litopenaeus vannamei) dengan Kombinasi Pakan Segar dan Pakan Buatan.

Sukarman dan Lili Sholichah. 2011. Status Mineral dalam Pakan Ikan dan Udang. Prosiding Forum Inovasi
Teknologi Akuakultur. Depok : Balai Riset Budidaya Ikan Hias.

Sumawidjaja, K. 1991. Penyakit Benih Udang Windu (Penaeus monodon Fabricus), Makalah Seminar Hasilhasil Penelitian, Institut Pertanian Bogor, 7 April.

Supamattaya, K., J. Kasornchandra and S. Boonyaratpalin. 1994. Comparative Study of Simple Methods for the Diagnosis of Yellow Head Diseases in the Black Tiger Shrimp (Penaeus monodon Fab.). Asean Shrimp News, 1st Quarter 1994. Thailand : 43-45.

Suprayudi, M.A., Indrastuti, L. dan Setiawati, M. 2006. Pengaruh Penambahan Bahan-bahan Imunostimulan dalam Formulasi Pakan Buatan Terhadap Respon Imunitas dan Pertumbuhan Kerapu Bebek (Cromileptes altivelis). Jurnal Akuakultur Indonesia, 5(1) : 77-86.

Suryaberata. 2004. Imunologi Dasar, 4st ed. Balai Penerbit Fakultas Kedokteran Unversitas Indonesia, Jakarta.

Suwono, Hidayat Suryanto dan Markus Mangampa. 2010. Pengaruh Lama Waktu Pemeliharaan Terhadap Pertumbuhan dan Sintasan Vaname pada Sistem Pertokolan. Sulawesi Selatan.

Taslihan, A. 1991. Jenis Penyakit yang Menyerang Udang Windu, Makalah disampaikan pada Workshop Penetapan Hama dan Penyakit Ikan Karantina, Bogor 10-12 September, 7-17.

Tizard I.R. 1988. Pengantar Imunologi Veteriner (Terjemahan). Airlangga University Press, Surabaya.

Tonguthai, K. 1991. Diseases of the Freshwater Prawn, Machrobrachium rosenbergii, AAHRI Newsletter 
Article, Vol 4 No. 2, Bangkok, Thailand.

Van de Braak, K. 2000. Haemocytic Defence in Black Tiger Shrimp (Penaeusmonodon), Disertation, Van Wareningen Universiteit, Germany.

Widodo, P. Dan Diyan. 2011. Aplikasi Probiotik, Prebiotik dan Sinbiotik Melalui Pakan pada Udang Vanname Litopenaeus vannamei yang Diinfeksi oleh Bakteri Vibrio harveyii, Fakultas Perikanan dan Kelautan, IPB.

Wyban, J.A. and Sweeney, J.N. 1991. Intensive Shrimp Production
Technology. Hawai : The Oceanic Institute.

World Wildlife Fund Indonesia. 2014. Budidaya Udang Vannamei Tambak Semi Intensif dengan Instalasi Pengolahan Air Limbah (IPAL). Jakarta Selatan

Xiaozhong $\mathrm{Hu}$ and Weibo Song. 2000. Description of Zoothamnium chlamydis sp. (Protozoa : Ciliophora : Peritrichida), an Ectocommenseal Peritrichous Ciliate from Cultured Scallop in North China, Laboratory of Protozoology, KLM, Ocean, Qingdao, University of Qingdao, Republic of China. 